\title{
ZAUFANIE DO WŁADZ PUBLICZNYCH. EFEKT ZAKLINANIA DESZCZU A INSTYTUCJONALIZACJA NIEUFNOŚCI
}

\section{Robert Sobiech*}

Abstrakt

Artykuł przedstawia wybrane stanowiska w toczonej od kilku dekad debacie dotyczącej kryzysu zaufania do władz publicznych. Jedną z kluczowych kwestii jest zapewnienie równowagi pomiędzy zaufaniem, niezbędnym do sprawnego funkcjonowania systemu demokratycznego, a uzasadnioną nieufnością obywateli, konieczną do ich społecznej kontroli. Pytanie to nabiera szczególnego znaczenia w sytuacji niskiego poziomu zaufania wobec władz publicznych i rosnącej popularności radykalnych ruchów społecznych i politycznych. Zdaniem wielu badaczy, zawodność dotychczasowych mechanizmów instytucjonalizacji nieufności stanowi istotne zagrożenie dla dotychczasowego porządku społecznego i politycznego.

Słowa kluczowe: zaufanie, nieufność, demokracja, zaufanie do instytucji, zaufanie do rządu, instytucjonalizacja nieufności

\section{INSTITUTIONAL TRUST.}

\section{RAINMAKING EFFECT AND INSTITUTIONALIZATION OF DISTRUST?}

Abstract

The paper presents selected positions emerging in debate over the causes and effects of trust in institutions that has been going on for several decades. One of the key issues is the question of the balance between trust, necessary for the efficient functioning of the democratic system, including public institutions, and the distrust of citizens, necessary for their social control. The above question becomes particularly important in a situation of low public trust in government and growing popularity of radical social and political movements. According to many researchers, the failure of the existing forms of institutionalization of distrust poses a significant threat to the current social and political order.

Keywords: trust, distrust, democracy, institutional trust, trust in government, institutionalization of distrust

\footnotetext{
*Dr Robert Sobiech, Collegium Civitas, e-mail: robert.sobiech@civitas.edu.pl
} 
Wstęp

Czy możemy ufać rządzącym? Pytanie to pojawia się w zarówno w analizach społeczeństwa nowoczesnego jak i w analizach społeczeństwa późnej nowoczesności. Zadawane jest w utworach masowej kultury, jak i w codziennych rozmowach. Na początku lat 60. blisko 3/4 Amerykanów deklarowało zaufanie do rządu. Po upływie ponad 50 lat, odsetek ufających rządowi nie przekracza 20\% (Pew Research Centre 2017). Podobne zmiany obserwowane są w innych państwach demokratycznych. Coraz częściej pojawiają się głosy o powszechnym kryzysie zaufania do władz publicznych i istotnych, negatywnych konsekwencjach dla organizacji społecznej, ładu ekonomicznego i politycznego. W wielowymiarowej dyskusji dotyczącej pożądanych reakcji na kryzys zaufania, szczególnie istotne wydają się następujące pytania: $\mathrm{W}$ jakim stopniu zaufanie wobec władz publicznych jest konsekwencją jakości rządzenia? W jaki sposób zapewnić równowagę pomiędzy zaufaniem, niezbędnym do sprawnego funkcjonowania systemu demokratycznego, a uzasadnioną nieufnością obywateli, konieczną do kontroli władz publicznych? Czy możliwy jest wysoki poziom społecznego zaufania wobec władz publicznych w warunkach znaczących nierówności społecznych i zwiększającego się zróżnicowania społeczeństw?

Niniejszy artykuł jest prezentacją wybranych stanowisk pojawiających się w dyskusji prowadzonej przez socjologów, politologów, ekonomistów czy badaczy zarządzania publicznego. Dyskusji, której znaczenie ujawnia się z coraz większą siłą w sytuacji znaczącej radykalizacji postaw społecznych, traktowanych przez wielu ekspertów jako istotne zagrożenie dla dotychczasowego porządku politycznego.

Niemal przez cały XX wiek problematyka zaufania postawała na marginesie zainteresowań socjologii. W XX wieku jedynie sporadycznie odnaleźć można prace, gdzie zaufanie było głównym tematem refleksji socjologicznej (np. Garfinkel 1963; Henslin 1972). Dopiero w ostatnich 
dwóch dekadach ubiegłego stulecia pojawily się prace wprowadzające problematykę zaufania do głównego nurtu zainteresowań socjologii. Przełomowym momentem była opublikowana w 1979 roku praca Niclasa Luhmanna Trust and Power (1979), gdzie zaufanie uznane zostało za podstawowy element życia społecznego. W połowie lat 9o. ukazuje się praca Anthony'ego Giddensa Politics, Sociology and Social Theory: Encounters with Classical and Contemporary Social Thought (1995), przedstawiająca znaczenie zaufania w społeczeństwie niepewności i ryzyka. W tym samym roku, o zaufaniu jako o kluczowym elemencie transakcji ekonomicznych pisze Francis Fukuyama (1995) W roku 1999 ukazuję się praca Pawła Sztompki Trust: A Sociological Theory, przedstawiająca całościową teorię zaufania. W 2007 roku Sztompka w swojej kolejnej książce Zaufanie. Fundament spoleczeństwa uznaje zaufanie za fundament społeczeństwa.

Pojęcie zaufania nierozerwalnie wiąże się z pojęciem ryzyka. Jak zauważa Anette Baier, „zaufanie polega na przekonaniu, że inni, tak daleko, jak się da, będą troszczyć się o nasze interesy, nie wykorzystują swoich przewag w celu wyrządzenia nam szkody. Zaufanie obejmuje słabości jednostki wynikające z jej braku pewności co do przyszłych zachowań innych osób. Ponieważ nie znamy przyszłych zachowań innych, możemy jedynie wierzyć, że nie wystawią nas na nowe, nieznane rodzaje ryzyk" (Bouckaert, Van de Walle, Maddens, Kampen 2002: 10). Dla Sztompki zaufanie jest formą zakładu dotyczącego przyszłych, niepewnych działań zachowań innych ludzi (Sztompka 1999).

Przyznanie, że zaufanie pojawia się w sytuacjach, w których pojawia się brak pewności, szczególnie silnie odnosi się do zmian współczesnych społeczeństw, gdzie tradycyjny lad społeczny, relacje międzyludzkie, trwałość instytucji społecznych dostarczały znacznej części obywateli poczucia kontrolowania własnej przyszłości. Społeczeństwa późnej nowoczesności stawiają ludzi w obliczu rosnącej niepewności, dotyczącej zachowań innych. Złożoność, a co za tym idzie nieprzewidywalność 
współczesnego świata, sprawia, że dla wielu ludzi zaufanie staje się instrumentem redukowania niepewności, sposobem na radzenie sobie z nieprzewidywalną przeszłością (Luhmann 1998).

Przemiany współczesnych społeczeństw, w tym przede wszystkim pojawienie się nowych zagrożeń i nieznanych obszarów ryzyka, sprawiły, że to właśnie zaufanie uznawane jest za kluczowy element integrujący (a zarazem stabilizujący) system społeczny. W opinii wielu ekspertów (OECD 2013) zaufanie jest także uznawane za konieczny warunek reform odpowiadających na obecne i przyszłe wyzwania XXI wieku. Kryzys ekonomiczny z 2008 roku i sprzeciw znacznej części europejskiej i amerykańskiej opinii publicznej wobec polityki cięć oszczędnościowych, sprawiły, że coraz częściej zaczęto mówić o wyczerpywaniu zaufania, widocznym zarówno w relacjach społecznych, relacjach gospodarczych, a przede wszystkim w relacjach pomiędzy obywatelami a władzą publiczną. Szczególnie silne zmiany postaw dotyczą zaufania do rządu. Tak np. wiosną 2007 roku zaufanie do rządu deklarowało 41\% mieszkańców państw Unii Europejskiej, a pięć lat później jedynie 24\% Wiosną 2015 roku zaufanie do rządu deklarowało mniej niż 20\% obywateli Polski, Francji, Hiszpanii czy Włoch (Public Opinion in the European Union 2015).

Podsumowując wyniki badań poświęconych problematyce zaufania Kenneth Newton, Dietlind Stolle, Somja Zmerli (2008: 47-51) formułują dwie interpretacje wyjaśniające uwarunkowania zaufania społecznego (social trust) i zaufania do politycznego (political trust) ${ }^{1}$.

Wedle pierwszej interpretacji, określanej jako „wygrani i przegrani”, zaufanie zależy zarówno od cech osobowości, wiarygodności otoczenia

' Według autorów artykułu zaufanie społeczne obejmuje zarówno zaufanie osobiste (personalized trust) wyrażane wobec osób, które znamy, jak i zaufanie uogólnione (generalized trust) wyrażane w stosunku do innych, nieznanych nam osób. Z kolei zaufanie polityczne obejmuje zarówno zaufanie do instytucji publicznych (np. służba cywilna, sądy, policja) jak i do instytucji politycznych (rząd, parlament, partie polityczne). 
społecznego, ryzyk pojawiających się w życiu codziennym, jak i od relacji z kluczowymi instytucjami społecznymi i politycznymi. Złożoność powyższych czynników wskazuje na wielowymiarowe uwarunkowania zaufania. Wyniki badań opinii publicznej w znaczący sposób wskazują na występowanie specyficznej konfiguracji cech. Okazuje się, że wyższym poziomem zaufania charakteryzują się osoby zamożne, zadowolone z życia, cieszące się dobrym zdrowiem, dobrze wykształcone, wysoko ulokowane na szczeblach społecznego i ekonomicznego statusu. Innymi słowy osoby, które można określić jako „wygranych” w życiu społecznym. „Wygranych”, którzy ufają swojemu otoczeniu zarówno ze względu na wyższe ryzyko utraty swojego statusu ale też dysponujący szerszym zestawem środków chroniących ich przed istniejącymi ryzykami. Na przeciwnych krańcach struktury społecznej znajdują się „przegrani”, charakteryzujący się największym poczuciem zagrożenia i najmniejszym poziomem bezpieczeństwa. To właśnie wśród „przegranych” odnotowuje się najmniejszy poziom zaufania, w tym przede wszystkim zaufania do systemu demokratycznego i władz publicznych.

Jak wskazują Newton, Stolle i Zmerli, bezpośrednio przez referendum dotyczącym Brexitu tylko 26\% Brytyjczyków o najniższych dochodach deklarowało zaufanie do rządu, to jest dwukrotnie mniej niż miało to miejsce wśród osób o najwyższych dochodach (54\%). Podobne różnice odnotowano w przypadku zaufania do innych instytucji; mediów, biznesu czy organizacji pozarządowych. Zwiększenie nieufności wobec instytucji publicznych wśród najgorzej sytuowanych kategorii społecznych odnotowano także w Stanach Zjednoczonych w okresie poprzedzającym wybór Donalda Trumpa. Według badania Edelman Trust Barometer w 2016 roku prowadzonego w 28 krajach, to właśnie Wielka Brytania i USA należały do nielicznej grupy państw gdzie odnotowano zwiększenie się różnic pomiędzy poziomem zaufania deklarowanym przez osoby o najniższych i najwyższych dochodach. (Newton, Stolle, Zmerli 2018: 50). Stąd też, nasilająca się nieufność wobec instytucji 
publicznych, w połączeniu z rosnącą popularnością ruchów populistycznych, traktowane są coraz częściej jako zagrożenie dla dotychczasowego kształtu systemu demokratycznego.

Inna interpretacja, sformułowana przez Newton, Stolle i Zmerli, odwołuje się do efektów stosowania zasad roli dobrego rządzenia² jako kluczowego czynnika wpływającego na zaufanie społeczne. To właśnie władze publiczne traktowane są jako swoisty „zaklinacz deszczu”, sprawiający że efekty rządzenia, podobnie jak deszcz spadają na całej społeczeństwo, niezależnie od istniejących różnic w poziomie zaufania. W takim rozumieniu, efekty dobrego rządzenia zwiększają zaufanie do instytucji publicznych i odwrotnie, błędy popełniane przez rządzących zwiększają społeczną nieufność. Autorzy przyznają, że mamy tu do czynienia z dwustronną zależnością. Zaufanie jest wynikiem dobrego rządzenia, ale też warunkiem dobrego rządzenia jest odpowiednio wyskoki poziom społecznego zaufania. Potwierdzają to wyniki badań prowadzonych w Szwecji, Finlandii, Nowej Zelandii i Japonii w drugiej połowie ubiegłego wieku. Pojawiające się w tym czasie liczne problemy gospodarcze i społeczne (recesja, inflacja, ograniczenia usług publicznych, spadek realnych dochodów) nie przełożyły się na trwały spadek zaufania społecznego (w niektórych przypadkach odnotowano nawet wzrost zaufania). Obserwowany w tym czasie spadek zaufania politycznego okazał się krótkotrwałym zjawiskiem. Poprawa sytuacji gospodarczej

\footnotetext{
${ }^{2}$ Dobre rządzenie (good governance) jest jedną z trzech dominujących koncepcji zarządzania publicznego. W przeciwieństwie do koncepcji rządzenia (govenrnance) i koncepcji nowego zarządzania publicznego (new public management), eksponuje ono m.in. udział obywateli w procesie podejmowania decyzji, dążenie do poszukiwana kompromisu pomiędzy zainteresowanymi stronami czy respektowaniem interesów mniejszości. Modele dobrego rządzenia opracowane przez organizacje międzynarodowe przedstawiają zasady, które powinny być stosowane przy tworzeniu i realizacji polityk publicznych. Tak np. Bank Światowy (Governance and Development 1992) wymienia zasady: głosu obywateli i rozliczalności, stabilności politycznej i braku przemocy, efektywności, jakości regulacyjnej, rządów prawa i kontroli korupcji. Komisja Europejska wskazuje na zasady otwartości, partycypacji, rozliczalności, efektywności i koherencji (European Governance 2001).
} 
zaowocowała przywróceniem wcześniejszego zaufania do polityki (Newton, Stolle, Zmerli 2018: 50).

Przedstawione interpretacje stanowią swego rodzaju syntezę toczonej od kilkudziesięciu lat dyskusji dotyczącej przyczyn i konsekwencji społecznego zaufania. Pomimo swojego uproszczonego charakteru sygnalizują one dwie kluczowe kwestie nierozerwalnie związane z kwestią zaufania. Pierwszą z nich jest kwestia nieufności, rozumiana zarówno jako destrukcyjna siła będąca zagrożeniem dla istniejącego porządku społecznego i politycznego, ale też jako nieodłączny element systemu demokratycznego, umożliwiający społeczna kontrolę władz publicznych. Drugą kwestią jest kwestia relacji pomiędzy zaufaniem wobec rządu a efektami i zasadami działania władz publicznych, w tym zagadnienie wpływu polityk „zaklinania deszczu” na społeczne postawy wobec rządzących.

Zaufanie w systemie demokratycznym - instytucjonalizacja zaufania, a instytucjonalizacja nieufności

Już w połowie XIX wieku Jeremy Bentham twierdził, że nieufność wobec rządzących jest naturalną reakcją na pokusy nadużywania władzy. Benjamin Constant uważał, że każda dobra konstytucja powinna być wyrazem nieufności wobec rządzących (Warren 2018: 75). Mamy tu do czynienia ze swoistym paradoksem. System demokratyczny zbudowany na nieufności jest jednocześnie systemem, którego niezbędnym warunkiem działania jest odpowiedni poziom zaufania.

Znalezienie optymalnych rozwiązań, łączących potrzebę zaufania do władz publicznych z potrzebą wyrażania nieufności od dłuższego czasu stanowi przedmiot zainteresowania socjologów, politologów, historyków reprezentujących różne podejście teoretyczne. Dla Charlesa Tilly (2007) demokracja oznacza dezintegrację istniejących sieci zaufania, opartych o zasady lojalności grupowej i dystrybucję korzyści wewnątrz 
sieci dokonywaną przez lokalnych patronów. Zastępują ją nowe formy integracji opierające się na sieciach zaufania tworzonych przez instytucje i stowarzyszenia posiadające silną publiczną legitymizację. Stąd też, kluczowym pytaniem dla stabilności systemu demokratycznego jest pytanie o odpowiednie proporcje pomiędzy zaufaniem a nieufnością.

Cechą współczesnych demokracji jest nieufność przejawiająca się niechęcią do powierzania legalnie wybranym władzom publicznym swoistych czeków in blanco. Zdaniem Tillego, sprawowanie władzy niezgodne ze społecznymi oczekiwaniami prowadzi zazwyczaj nie tylko do odebrania uprzednio wystawionych czeków ale także do wycofania zgody na wypełnianie obowiązków nakładanych przez państwo (np. służba wojskowa, płacenie podatków). Z drugiej strony, system demokratyczny wspomaga budowanie zaufania. Istotną rolę odgrywają tu liczne gwarancje bezpieczeństwa, jak i respektowanie zasady rządów prawa. Znaczącym wsparciem dla społecznego zaufania są rozwiązania polityk publicznych ograniczające uzależnienie obywateli od klientystycznych układów czy zwiększające równość szans (system edukacyjny).

Analizując związki pomiędzy zaufaniem a demokracją, Mark Warren zadaje dwa kluczowe pytania: „W jakim stopniu demokracja wymaga zaufania? Jaki rodzaj zaufania i braku zaufania osłabiają (korodują) demokrację?" (Warren 2018: 75). Warren, podobnie jak inni badacze (Norris 1999) rozumie zaufanie jako przekonanie jednostki, że inni ludzie (działający indywidualnie lub w swoich instytucjonalnych rolach) są zmotywowani i kompetentni do działań realizujących interesy jednostki. Kluczową rolę odgrywają tu relacje zaufania (trust relationships), pojawiające się w sytuacji, kiedy przekonania o istnieniu zaufania współwystępują z wiarygodnymi reakcjami osób, które obdarzamy zaufaniem. Takie właśnie relacje zaufania zapewniają bezpieczeństwo i poczucie pewności, niezbędne do funkcjonowania systemu społecznego. Są również niezbędnym elementem funkcjonowania systemu demokratycznego. Niezależnie od istniejących zróżnicowań, większość 
systemów demokratycznych charakteryzuje się podobnymi mechanizmami instytucjonalizacji relacji zaufania. Warren wyróżnia następujące mechanizmy: ochrona uogólnionego zaufania: oddzielanie domeny (sfery) politycznej rządu od administracji publicznej, kanalizowanie nieufności w ramy istniejących domen politycznych oraz wzmacnianie społecznych mechanizmów monitorowania działań władz publicznych (Warren 2018: 77).

Do mechanizmów ochrony zaufania należy swoboda działania stowarzyszeń i innych form aktywności obywatelskiej, opartych na relacjach zaufania ich uczestników. Istotnym zabezpieczeniami są także gwarancje wolności wypowiedzi, a także możliwości odwoływania się od arbitralnych lub dyskryminujących działań państwa. Istotną rolę pełni także oddzielenie domeny politycznej od domeny administracji. Sfera polityczna obejmuje zarówno działalność władz ustawodawczych i wykonawczych, partii politycznych ale także działalność części władzy sądowniczej. Domena polityczna to obszar ścierania się (lub rozstrzygania) mniej lub bardziej partykularnych interesów, gdzie zaufanie pojawia się stosunkowo rzadko. O wiele częściej deklarowane jest ono w przypadku administracji publicznej, gdzie znaczna część instytucji postrzegana jest jako podmioty działające na rzecz dobra wspólnego (np. straż pożarna, policja, edukacja), w przeciwieństwie do domeny politycznej ze swej istoty nastawionej na wpływ grupowych interesów realizację agend politycznych.

Ochrona zaufania to także kanalizowanie nieufności. Kluczową rolę pełni tu system polityczny zapewniający podejmowanie decyzji w warunkach konfliktu, ścierania się różnorodnych, często przeciwstawnych interesów. Szczególna rola przypada tu władzy ustawodawczej i władzy sądowniczej, a także politycznym sferom władzy wykonawczej. To właśnie one odpowiedzialne są za instytucjonalizację nieufności, polegającą na kanalizowaniu nieufności, przeciwdziałając przeniesieniu nieufności na inne instytucje władzy wykonawczej odpowiadające na istniejące 
potrzeby społeczne i dostarczające powszechnie akceptowanych usług publicznych. Tak rozumiana instytucjonalizacja nieufności sprawia, że brak zaufania kierowany jest przede wszystkim wobec domeny politycznej i nie jest uogólniany na pozostałe instytucje publiczne.

Niemniej ważnym elementem ochrony zaufania są procedury kontroli i monitorowania działań władzy. Demokracja nie może obyć się bez instytucji umożliwiających społeczny nadzór nad sposobami rozstrzygania zróżnicowanych interesów i rozwiązywania konfliktów. Przykładem takiej instytucji jest wiarygodny system wyborczy, utrwalający przekonanie o możliwości zmiany partii rządzących. Istotną rolę odrywają niezależne media będące zarówno instytucją kontroli władzy, jak i miejscem debaty publicznej.

Kolejnym elementem są niezależne instytucje kontrolne będące częścią systemu politycznego (w Polsce Najwyższa Izba Kontroli czy Rzecznik Praw Obywatelskich), a także szeroko rozumiane organizacje strażnicze czy organizacje pozarządowe realizujące różne formy rzecznictwa obywatelskiego. Sama władza wykonawcza dysponuje również szeregiem instrumentów umożliwiających społeczną kontrolę nad jej działalnością. Należą do nich systemy ewaluacji i monitorowania polityk publicznych, regulacje dostępu do informacji publicznej czy konsultacji publicznych. We wszystkich omawianych przypadkach kluczową rolę odgrywa wiarygodność i rzetelność mechanizmów kontroli i wiarygodność samych instytucji. Tylko przy spełnieniu tych warunków może pojawić się podzielane przekonanie, że instytucje kontroli i nadzoru stanowią skuteczny hamulec chroniący przed możliwymi nadużyciami rządzących, stanowiąc jeden z filarów społecznego zaufania.

Według Pierre’a Rosanvallona, nieufność jest uznawana za kluczowy element konstytuujący życie społeczne i wyjaśniający jego przemiany. Nieufność jest także nieodłącznym elementem demokracji (Szlaszyńska 2008). Rosanvallon mówiąc o współczesnym społeczeństwie określa je wręcz jako społeczeństwo nieufności. Nieufność jest także swoistą reakcją 
społeczną na kryzys systemu przedstawicielskiego. Stąd też, Rosanvallon w swoich analizach odwołuje się często do pojęcia kontr-demokracji. Utrzymanie społecznego mandatu udzielonego rządzącym nie zależy tu jedynie od jakości rządzenia ale przede wszystkim od funkcjonowania mechanizmów społecznego nadzoru, określanych jako władzę nadzoru. Wykonywanie takiej władzy wymaga wykorzystania trzech instrumentów. Pierwszy z nich określany jest mianem czujności, rozumianej jako tworzenie instytucjonalnych ograniczeń, chroniących przed nadużyciami władzy. Drugim instrumentem jest donos, rozumiany jako ujawnianie niewygodnych, niepożądanych przez rządzących informacji. Kluczową rolę pełnią tu media, dla których ujawnienie faktów ukrywanych przed opinią publiczną stanowi jednej z filarów ich misji. Trzeci instrument, to ocena władz publicznych dokonywana przez opinię publiczną. Podstawą takiej oceny są często efekty działań publicznych ujawniane w raportach monitorujących i oceniających działania władz publicznych (Szlaszyńska 2008: 257-259).

Jak zauważa Rosanvallon, reakcje na kryzys systemu demokratycznego, to z jednej strony wysilki na rzecz ulepszenia „demokracji wyborczej”, ale także działania zmierzające do „wyrównanie spadku zaufania poprzez organizację nieufności” (Rosanvallon 2008b: 270). Zdaniem Rosanvallona stoimy dziś przez kluczowym wyzwaniem modyfikacji systemu demokratycznego. Narastająca społeczna nieufność wobec zasad wyłaniania władz publicznych i metod kontroli ich działalności (przy niemal powszechnej aprobacie samej demokracji), sprawia że kluczową kwestią staje się organizacja nieufności. Nieufność może być zarówno chorobą demokracji, może być także jej lekarstwem, jeśli zostanie wkomponowana w istniejące rozwiązania ustrojowe (równoważenie władz) czy instytucjonalne. Innymi słowy, narastająca nieufność wobec instytucji może wzmacniać system demokratyczny, jeżeli towarzyszy jej przekonanie o możliwej zmianie społecznej (Ibidem). 
Zaufanie do rządu jako element zaufania do instytucji

Zdaniem Clausa Offe instytucje są systemami zasad, które odnoszą się do przyszłych działań aktorów (Offe 2006). To właśnie instytucje są substytutem zaufania (Offe 1999). Zaufanie, nie wynika z oceny pracujących w nich ludzi, a jest w znacznym stopniu efektem oceny procedur i mechanizmów gwarantujących jakość oferowanych przez nich usług.

Zdaniem Olivera Williamsona (1993) zaufanie instytucjonalne obejmuje zaufanie do instytucji politycznych, regulacyjnych, reprezentacji zawodowych czy przedsiębiorstw. Mechanizmy równoważenia się władz (check and balances), regulacje, certyfikaty wydawane przez ekspertów w różnych sferach życia stanowią swego rodzaju zachęty do ufania instytucjom. Z drugiej strony, gwarancje zawarte w różnych formach kontraktów i umów wymagają uprzedniego zaufania do instytucji Dotyczy to szczególnie tych obywateli, których interesy nie są dostatecznie chronione innymi rozwiązaniami (Hardin 2002). Zdaniem Williamsona, zaufanie instytucjonalne jest swego rodzaju kalkulowanym ryzkiem. Ryzykiem ograniczanym zabezpieczeniami i ubezpieczeniami oferowanymi przez otocznie instytucjonalne.

Stąd też Williamson mówi wręcz o zaufaniu „występującym z łącznikiem" (hyphenated trust), gdzie racjonalna kalkulacja i gwarancje (stanowiące istotę rządzenia) powinny współwystępować ze stabilnością otoczenia instytucjonalnego. Stabilne instytucje sprawiają, że zaufanie instytucjonalne okazuje się bardziej efektywne niż zaufanie interpersonalne.

Wielu badaczy zauważa jednak, że zaufanie interpersonalne jest niezbędnym warunkiem pojawienia się zaufania instytucjonalnego. Zdaniem Frensa Kroegera (Cook, Santana 2018: 271) zmniejszenie zaufania interpersonalnego występującego w mechanizmach działalności instytucji, prowadzi często do niestabilności lub załamania instytucji. Szczególnie widoczne jest to w przypadku instytucji finansowych, gdzie zaufanie traktowane jest oczywistość wynikająca z istniejących gwarancji. 
Klienci tych instytucji obdarzają takim zaufaniem swoich maklerów, ci z kolei ufają menadżerom funduszy hedgingowych, ci zaś ufają bankom, które obdarzają zaufaniem giełdy. Taka „spirala eskalacji systemu zaufania” znacząco zwiększa ryzyko załamania całego systemu finansowego.

Zagadnieniem przyciągającym szczególną uwagę w analizach zaufania instytucjonalnego jest zaufanie do rządu. Uznanie, że zaufanie jest nierozerwalnie związane z niepewnością dotyczącą przyszłych działań drugiej strony, oznacza, że władze publiczne dysponują stosunkowo dużym obszarem swobody w swoich działaniach. Przy takim założeniu, zaufanie stanowi niezbędny element trwałości systemu politycznego i społecznej legitymacji rządzących. Zdaniem części badaczy (Bouckaert, Van de Walle, Maddens, Kampen 2002), powyższe założenie tylko w niewielkim stopniu przystaje do współczesnych realiów. W większości państw liberalnej demokracji władze są w znacznym stopniu związane ograniczeniami stanowiącymi podstawę porządku demokratycznego. Sama koncepcja państwa prawa (Rechtstaat), zakładająca prymat prawa, wyznaczającego kompetencje rządzących i gwarancję praw obywatelom, sprawia, że zaufanie do rządu nie jest decydującym czynnikiem w społecznych ocenach władzy publicznej. W im większym stopniu państwo jest postrzegane jako państwo prawa, tym mniejsze znaczenie posiada zaufanie. Stąd też, w państwach charakteryzujących się ograniczoną kontrolą działalności rządu, szczególnie w systemach totalitarnych, zaufanie (a przede wszystkim nieufność) jest kluczowym elementem wyznaczającym społeczne postaw wobec rządzących.

Charakterystyczne dla państw rozwiniętych, znaczące zmniejszanie zagrożeń takich jak utrata wolności, życia czy głód, stanowiące do niedawna przedmiot obaw znacznej części obywateli, przyczyniają się do zmniejszenia roli zaufania i wzrostu znaczenia takich czynników jak jakość, usług publicznych, reagowanie na potrzeby obywateli czy możliwość udziału w życiu publicznym. Stąd też, w tych społeczeństwach, to nie obawa przed nieprzewidzianymi zagrożeniami, stanowi istotę zaufania, 
a poczucie pewności (confidence), oznaczające, że obecne rozwiązania i procedury pozostaną niezmienne (Luhnman 1998).

Zdaniem Hardina, zaufanie do rządu oznaczać może zaufanie do ludzi pracujących w instytucjach władzy wykonawczej, może też być rozumiane jako zaufanie do instytucjonalnego systemu ról i zachęt, wspierających realizacje naszych interesów (Hardin 1998). W pierwszym przypadku zaufanie do rządu kształtowane jest w ramach bezpośrednich kontaktów z, nieliczną grupą pracowników agend rządowych. W drugim, odwołuje się do, zazwyczaj wysoce niepełnej wiedzy obywateli o funkcjonowaniu instytucji władzy wykonawczej.

Odrębną kwestią, dodatkowo komplikującą analizy zaufania do rządu, jest brak zgody badaczy jak rozumiane jest pojęcie rządu przez obywateli. Czy zaufanie do rządu oznacza zaufanie do instytucji władzy wykonawczej (rada ministrów, ministerstwa, urzędy centralne)? Czy zaufanie do rządu powinno być utożsamiane $\mathrm{z}$ zaufaniem do usług publicznych świadczonych przez władzę wykonawczą (edukacja, zdrowie, bezpieczeństwo)? A może chodzi tu o zaufanie do polityków sprawujących władzę, czy administrację rządową realizującą wybrane agendy polityczne.

Część badaczy pomija powyższe pytania, przyjmując założenie o współwystępowaniu cząstkowych ocen dotyczących instytucji władzy wykonawczej, formułowanych na podstawie indywidualnych doświadczeń czy wiedzy o działalności rządu, w jedną zgeneralizowaną ocenę widoczną w wynikach badań opinii publicznej (Mishler, Rose 1997; Stipak 1979; Loveless 1997).

W teoretycznej refleksji dotyczącej zaufania do rządu stworzono szereg, często wzajemnie pokrywających się modeli. Sako (1992) proponuje rozróżnienie na zaufanie kontraktu, zaufanie kompetencji i zaufanie „dobrej woli”, (contractual trust, competence trust, goodwill trust). Lewicki i Bunker (1996) mówią o zaufaniu opartym na analizie, wiedzy i tożsamości (calculus-based, knowledge-based, identification-based 
trust). Bouckaert (2012) przyjmuje za kluczowe trzy wymiary zaufania: zaufanie instytucjonalne, zaufanie oparte na analizie i zaufanie relacji.

Zaufanie instytucjonalne odwołuje się do istniejących systemów wsparcia, ograniczających różne rodzaje ryzyk do minimalnego możliwego do osiągnięcia i akceptowalnego społecznie poziomu. Taką rolę pełni system prawa, który oprócz swoich funkcji kontrolnych jest znaczącym czynnikiem ograniczającym ryzyko. Podobną rolę może także odgrywać profesjonalna administracja, ustanawiająca zasady i procedury, chroniące obywateli przed zagrożeniami, dając poczucie pewności i przewidywalności.

Zaufanie instytucjonalne podtrzymywane jest i wzmacnianie poprzez klarowne określenie praw i obowiązków, przekładając się na poczucie przewidywalności i świadomość ochrony przez istniejącymi ryzykami. Znacząca rolę odgrywa tu profesjonalizm, przejrzystość reguł, a przede wszystkim zdolność do rozstrzygania konfliktów w ramach rzetelnych i uczciwych procesów. Tak rozumiane zaufanie instytucjonalne oparte jest na zrozumieniu znaczenia ustanowionych reguł i konsekwencji ich naruszania. Dostosowanie do zasad i regulacji dostarcza systemowych gratyfikacji, ich naruszanie wiąże się z wyłączaniem z systemu i izolacją. Stąd też, zachwianie zaufania do instytucji oznacza zazwyczaj redefiniowanie zasad i regulacji, niezbędne do uczynienia instytucji bardziej przewidywalnymi.

Zaufanie oparte na analizie odwołuje się do sfery racjonalnych wyborów dokonywanych przez obywateli. Kluczowe znaczenie odgrywa tu ekonomiczna kalkulacja zysków i strat, efektów transakcji i wymian mających miejsce sferze publicznej. Warunkiem zaufania jest dostępność i transparentność informacji uzasadniających istniejące bądź nowo wprowadzane rozwiązania. Równie istotnym czynnikiem jest dostarczanie wiedzy o efektach działania sektora publicznego, wspierane przekonaniem, że działania sektora publicznego poddawane są systematycznemu audytowi i ocenie. Posiadanie takiej wiedzy zwiększa możliwości 
przewidywania zachowań innych podmiotów, prowadzi także do dwustronnej komunikacji pomiędzy obywatelami a władzami publicznymi, umożliwiając wyrażanie potrzeb, oczekiwań i opinii dotyczących preferowanych form rozwiązań odczuwanych problemów społecznych.

Podstawą zaufania opartego na relacjach (określanego także jako zaufanie relacyjne) jest ocena istniejących powiązań jednostki z innymi ludźmi. Zaufanie relacyjne zależy od szacunku dla roli pełnionej przez inne osoby, ale też od oceny kompetencji niezbędnych do wykonywania danej roli i uczciwością postępowania (Bryk, Schneider 2002). Zaufanie relacyjne jest także kluczowym komponentem zaufania do władz publicznych. W tym przypadku, zaufanie jest w dużej mierze oparte na grupowej identyfikacji potrzeb, intencji, ale także na wspólnym rozumieniu celów grup i ich otoczenia instytucjonalnego. Przekłada się ono na gotowość do tworzenia partnerstw, zaangażowanie w wolontariat czy podzielanie wizji polityk publicznych. Widoczne jest w różnych formach wspólnego planowania, realizacji i oceny działań publicznych.

Zaufanie do rządu a kryteria oceny władz publicznych

Przedstawiane koncepcje zaufania odzwierciedlają dwie dominujące interpretacje czynników wyznaczających zaufanie do władz publicznych. Pierwsza z nich, określane przez Bouckaerta, logiką konsekwencji (logic of consequences) eksponuje znaczenie nakładów i rezultatów zarządzania sektorem publicznym oraz znaczenie działań władz publicznych (zarządzanie zasobami ludzkimi, praktyki budżetowe, zarządzanie regul2cjami, realizacja polityk publicznych). Zgodnie z tą perspektywą, zaufanie zależy w decydującym stopniu od wyników i rezultatów działań publicznych. Społeczeństwo jest tu przede wszystkim odbiorcą usług czy beneficjentem polityk publicznych, a wskaźnikami zaufania do władz publicznych są zarówno satysfakcja klientów usług publicznych, wymierne efekty polityk publicznych (np. polityki edukacji, bezpieczeństwa, 
ochrony zdrowia), jak i efektywność polityk publicznych, przejawiająca się w pozytywnym bilansie nakładów i korzyści.

Jak twierdzi Bouckaert, stosowanie logiki konsekwencji jest jedynie koniecznym ale nie wystarczającym warunkiem zaufania do władz publicznych. Kluczową rolę pełni tu logika odpowiedniości (logic of appropriateness). Podstawą zaufania są tu przede wszystkim oceny obywateli dokonywane w oparciu o wartości wyznaczające działania władz publicznych. Logika odpowiedniości eksponuje znaczenie uczciwości, otwartości i reagowania na potrzeby obywateli.

Zdaniem Bouckaerta (2012) zaufanie do rządu, powinno być analizowane na trzech poziomach. Pierwszy z nich to poziom makro, gdzie zaufanie dotyczy instytucji politycznych i funkcjonowania demokracji. Na poziomie mezzo, zaufanie dotyczy tworzenia polityk publicznych, to jest zdolności rządów do zarządzania gospodarką i rozwiązywania problemów społecznych, generowania pozytywnych oczekiwań dotyczących przyszłych warunków życia. Wreszcie, na poziomie mikro, zaufanie odnosi się do wpływu rządu na codzienne życie ludzi, w tym wpływu wywieranego przez oferowane usługi publiczne.

Współwystępowanie wymienionych powyżej poziomów zaufania sprawia, że niepowodzenia w jednym z nich, niezależnie od sukcesów w pozostałych sferach mogą w znaczący sposób przekładać się na uogólnione oceny społeczne. Tak np. przekonanie o dysfunkcjonalności całego systemu instytucjonalnego czy przekonanie o zawodności reguł demokratycznych mogą być powodem społecznej nieufności, nawet w sytuacji empirycznie potwierdzonej skuteczności polityk publicznych czy zadowolenia obywateli z otrzymywanych usług. Na tej samej zasadzie, zadowolenie z funkcjonowania instytucji demokratycznych może być niewystarczającym warunkiem społecznego zaufania, w sytuacji drastycznych cięć ograniczających dostęp do usług zdrowotnych czy edukacyjnych. Stąd też, zaufanie wyznaczane jest zarówno rezultatami działań rządu, jak samym procesem prowadzących do ich osiągania. 
Społeczne oceny rządu kształtowane są w znacznym stopniu przez oczekiwania obywateli dotyczące władzy publicznej. Eksperci OECD w swoim raporcie z roku 2013 za najważniejsze oczekiwania uznają: rzetelność (reliability), responsywność (responsiveness), otwartość i włączanie (openness and inclusiveness), uczciwość (integrity) i bezstronność (fairness).

Rzetelność rozumiana jest jako zdolność rządów do minimalizacji niepewności w sferze gospodarczej, społecznej i politycznej oraz spójnych, przewidywalnych zachowań władz. Responsywność oznacza świadczenie dostępnych, efektywnych i zorientowanych na obywatela usług publicznych, które stanowią skuteczną reakcję na istniejące potrzeby i problemy. Otwartość i integracja polegają na budowaniu instytucjonalnych rozwiązań umożliwiających dwukierunkową komunikację z interesariuszami, dostarczeniu użytecznych dla nich informacji. Taka interakcja jest jednocześnie instrumentem zwiększającym transparentność, rozliczalność i włączenie zainteresowanych stron w proces decyzyjny. Uczciwość oznacza zgodność działania instytucji publicznych z zasadami i normami postępowania, które przyczyniają się do ochrony interesu publicznego, czy ograniczania korupcji. Bezstronność, to jednakowe traktowanie obywateli (ale także przedsiębiorstw) w tworzeniu i wdrażaniu polityk publicznych.

Bouckaert de Walle, Maddens i Kampen (2002) umieszczają kryteria ocen władz publicznych na kontinuum, którego końce wyznaczone są z jednej strony przez oceny efektów działań, z drugiej zaś poczuciem przynależności do wspólnoty państwa (performance vs. identity). W pierwszym podejściu charakterystyczne dla zrzeszeń procesy modernizacji i różnicowania struktury społecznej sprawiają, że oceny władzy dokonywane w oparciu o racjonalne, instrumentalne kalkulacje zysków i strat dla poszczególnych grup społecznych. W drugim, oceny rządu uzależnione są od emocjonalnych związków łączących uczestników wspólnoty lub wyznaczane są przez lojalność wobec charyzmatycznych 
czy tradycyjnych przywódców. Podobnego rozróżnienia dokonują Risto Harisalo i Ensio Miettinen (1997) mówiąc o systemie komunitariańskim i systemie „wioski biznesowej”. W pierwszym przypadku zaufanie do rządu jest oparte na wierze, w drugim jest wynikiem uczestnictwa i doświadczeń.

Innym problemem jest kwestia w jakim stopniu zaufanie do rządu dotyczy elit politycznych obecnie sprawujących władzę, w jakim zaś odwołuje się do ocen systemu politycznego jako całości. Analizy kryzysów legitymacji władz publicznych (Norris 2011) wykazują, że społeczne oceny są zarówno efektem społecznego rozczarowania skutecznością polityk publicznych, negatywną oceną uczciwości i jakości elit politycznych, jak i rozczarowaniem dotyczącym nieprzestrzegania kluczowych wartości systemu politycznego. Ocena władz publicznych jest tu często kompilacją ocen opartych na racjonalnej kalkulacji rezultatów, jak i ocen, mających swoje źródło w szeroko podzielanych wartościach i normach.

Dyskusja dotycząca kryteriów ocen władz publicznych łączy się w znacznym stopniu z refleksją dotyczącą ról pełnionych przez obywateli w życiu publicznym. Zdaniem Pula Epsteina, Lyle Wraya, Marrthy Marshall i Stuarta Grifela (2000) możemy mówić o 6 dominujących rolach będących zarówno ilustracją kluczowych oczekiwań wobec władz publicznych, jak i ukazujących odmienne pozycje poszczególnych aktorów w zróżnicowanej strukturze współczesnych społeczeństw. Pierwsza z wymienianych ról, to rola klientów, związana przede wszystkim z korzystaniem ze świadczonymi przez państwo usługami publicznymi. Drugą rolą jest rola właścicieli, udziałowców (owners/shareholders), gdzie obywatele traktowani są jako współwłaściciele sektora publicznego. Kluczowymi oczekiwaniami są tu oczekiwania dotyczące efektywności wydawania środków publicznych, skuteczności władz w rozwiązaniu problemów społecznych czy zgodności funkcjonowania władzy ze standardami etycznymi. Kolejna rola, to rola farmerów problemów 
publicznych issue farmers, zainteresowanych nie tylko wynikami działań rządu ale też uwzględnieniem w tych działaniach wartości i oczekiwań społecznych. Odmienny rodzaj oczekiwań reprezentują współproducenci usług publicznych, to jest osoby i grupy włączone w procedury świadczenia usług czy w rozwiązywanie problemów społecznych. Kolejną rolę pełnią osoby bezpośrednio zaangażowane w ocenę jakości usług publicznych (service quality evaluators), formułujące swoje oceny w badaniach konsumenckich ale też zgłaszające swoje opinie i roszczenia w ramach istniejących form kontaktu rządu z obywatelami. Ostatnią z wymienianych ról jest rola niezależnych strażników rezultatów działań publicznych (independent outcome trackes), pełniona zazwyczaj przez uczestników ruchów społecznych, organizacji strażniczych, czy niezależnych grup monitorujących proces i efekty działań publicznych.

Dyskusja dotycząca kryteriów oceny władz publicznych w znacznej mierze wyznaczane jest przez stosunek do koncepcji Nowego Zarządzania Publicznego (NPM). Zainicjowane głośną pracą Davida Osborna i Teda Gaeblera (Osborne, Gaebler 2005) podejście, postulujące przeniesienie do sektora publicznego niektórych mechanizmów zarządzania stosowanych w sektorze prywatnym, proponowało jako dominującą perspektywę, postrzeganie obywateli jako klientów usług publicznych. Ostatnie lata to okres stopniowego rozczarowania realizacją założeń NPM. Jednym z elementów sprzeciwu wobec perspektywy proponowanej przez NPM jest właśnie zbyt silne redukowanie obywateli do roli klienta, pomijając tym samym szereg istotnych oczekiwań społecznych wobec władz publicznych. Perspektywa klienta oznacza koncentrację zainteresowania na aktywnych, aktualnych użytkownikach usług publicznych (pamiętając, że część z tych usług nie zależy od wyborów ludzi), korzystających z usług publicznych w przeszłości, bądź na osobach zainteresowanych poszczególnymi usługami ale z rozmaitych powodów, wykluczonych z grona ich odbiorców. 
Perspektywie klienta przeciwstawiana jest perspektywa obywatela. Zainteresowanie działalnością władz publicznych nie ogranicza się w tym przypadku, do roli klienta, na pierwszy plan wysuwają się tu kryteria oceny związane z uczestnictwem w systemie demokratycznym. Stąd też, oceny usług publicznych dokonywane są także w sytuacjach gdy sami nie są ich odbiorcami.

Wedle innych opinii, zaufanie jest w znacznym stopniu niezależne od korzyści uzyskiwanych z wdrażania poszczególnych polityk publicznych ale wynika z korzystnego postrzegania działań rządu w sferze polityki. Oznacza to, że oceny rządu dokonywane są nie tylko przez konsumentów dóbr i usług ale także przez obywateli rozumianych jako konsumentów szeroko rozumianej polityki.

„Jeśli kryterium działania/wyników staje się podstawowym wyznacznikiem ocen mogą oni (obywatele) wspierać obecny system instytucjonalny i rozwiązania administracyjne, obdarzając zaufaniem rząd tak długo, jak dobra usługi dostarczane są im w satysfakcjonującej ilości i formie”, twierdzą Terrnce Mitchell i William Scott (1987: 452).

Istotną częścią badań nad determinantami zaufania jest wyjaśnienie w jakim stopniu społeczne oceny są efektem oceny wyników działań publicznych, w jakim zaś oceną procesu, rozumianego jako respektowanie zasad i wartości (uczciwość, życzliwość) w działaniach publicznych. Zaufanie często nie jest traktowane wyłącznie jako konsekwencja skuteczności rządu, w dużym stopniu zależy ono od symbolicznych gratyfikacji uzyskiwanych przez obywateli w procesie dostarczania usług publicznych (Easton 1965). Wyniki innych badań ujawniają, że powodem niezadowolenia z pracy rządu jest ocena polityk publicznych i ich wyników, zaś w przypadku władz ustawodawczej negatywne oceny maja swoje źródło w niezadowoleniu dotyczącym procesu osiągania wyników (Hibbing, Theiss-Morse 1995). 
Podsumowanie

Różnorodność koncepcji opisujących uwarunkowania społecznego zaufania do władz publicznych przekonuje, że dobre rządzenie rozumiane jako tytułowe zaklinanie deszczu jest skomplikowanym procesem dokonującym się w wśród zróżnicowanych oczekiwań, rozbieżnych interesów i odmiennych wartości. Przekonuje także, że profesja zaklinacza deszczu nie może ograniczać się wyłącznie do technicznej sprawności w planowaniu i implementacji polityk publicznych czy oferowaniu wysokiej jakości usług publicznych. Wymaga także zrozumienia wartości i emocji wyznaczających społeczne oceny władz publicznych. Koncepcja dobrego rządzenia, określana często mianem współrządzenia, i wyłonione z niej zasady zarządzania sprawami publicznymi wskazują na kluczową rolę włączania obywateli w procesy rządzenia. Można sądzić, że realizacja takich zasad jak zasada partycypacji, transparentności czy rozliczalności powinny przekładać się na wkomponowanie znacznej części nieufności społecznej w istniejące rozwiązania instytucjonalne. Czy jednak wprowadzane w życie mechanizmy udziału obywateli stanowią wystarczają gwarancję trwałości systemu społecznego i porządku politycznego?

Liczne analizy (How's Life? Measuring Well-being 2017) wskazujące na poprawę warunków życia w państwach demokratycznych (pomimo znaczącego niekiedy regresu wywołanego kryzysem ekonomicznych 2008 roku) sugerują, że polityki „zaklinania deszczu”, w znaczący sposób przyczyniają się do stabilizacji porządku społecznego.

Problemem pozostaje natomiast nierównomierny podział pozytywnych efektów poszczególnych polityk publicznych. Pomimo, że wzrost ekonomiczny i działania władz publicznych „podnoszą wszystkie łódki”, to w wielu sytuacjach, korzystają na tym przede wszystkim „wygrani”. 
Można sądzić, że to właśnie nierówności w podziale społecznych i ekonomicznych korzyści są bezpośrednią przyczyną rosnącego poczucia niezadowolenia osób przypisujących sobie status „przegranych”.

W 2015 roku zaufanie do rządu deklarowało 36\% obywateli państw Unii Europejskiej, którzy prawie nigdy nie mieli problemów z płaceniem rachunków i jedynie $18 \%$ osób, dla których problemy z płaceniem rachunków były stałym elementem ich życia (Public Opinion In the European Union 2015). Obserwowane w wielu państwach rozczarowanie obywateli modelem demokracji liberalnej niesie ze sobą ryzyko zawodności dotychczasowych form instytucjonalizacji nieufności, a co za tym idzie ryzyko przeniesienia nieufności, wyrażanej dotychczas przede wszystkim wobec sfery polityki, na instytucje bezpośrednio odpowiedzialne za dostarczanie usług publicznych. W tej sytuacji, nie dziwi wzrost popularności radykalnych ugrupowań pretendujących do reprezentacji „przegranych”, wykorzystujących niski poziom społecznego zaufania, do radykalnej zmiany obecnego porządku społecznego i politycznego.

Bibliografia

Bouckaert G. (2012). Trust and public administration, "Administration" Vol. 6o, No. 1

Bouckaert G., Van de Walle, S., Maddens, B., Kampen, J. (2002), Identity vs. performance: An overview of theories explaining trust in government. Second report on quality and trust in government, Public Management Institute, Leuven

Bryk, A., Schneider B., (2002), Trust in schools: A core resource for improvement, Russell Sage Foundation, New York

Cook K., Santana J. (2018), Trust and Rational Choice, w: Oxford Handbook of Social and Political Trust, (ed.) Uslaner E., Oxford University Press, Oxford 
Easton D., (1965) A System Analysis of Political Life, Wiley, New York Epstein P., Wray l., Marshall M., Grifel S. (2000), Engaging Citizens in Achieving Results that Matter: A Model for Effective 21st Century Governance, Proceedings of the ASPA CAP Symposium on Resultsoriented Government, Washington, DC

European Governance (2001), A White Paper, European Commission, Brussels

Fukuyama F. (1995), Trust: The Social Virtues and the Creation of Prosperity, Free Press, New York

Garfinkel H. (1963), A Conception of, and Experiments with 'Trust' as a Condition of Stable Concerted Actions, w: Motivation and Social Interaction: Cognitive Determinants, (ed.) Harvey O.J., Ronald Press Co., New York

Giddens A. (1995), Politics, Sociology and Social Theory: Encounters with Classical and Contemporary Social Thought, Stanford University Press, Stanford

Governance and Development (1992), The World Bank, Washington Hardin R. (1998), Trust in Government, w: Trust and Governance, (eds.) Braithwaite V., Levi M., Russell Sage Foundation, New York Hardin R. (2002), Trust and Trustworthiness, Russell Sage Foundation, New York

Harisalo R., Miettinen (1997), Trust capital. The third force of entrepreneurship, Tampere University. Department of Administrative Sciences, Tampere

Henslin J.M. (1972), What Makes for Trust? w: Down to Earth Sociology, (ed.) Henslin J.M., Free Press, New York

Hibbing J.R., Theiss-Morse E. (1995), Congress as Public Enemy: Public Attitudes Toward American Political Institutions, Cambridge University Press, New York

How's Life? Measuring Well-being (2017), Organisation for Economic Co-operation and Development, Paris 
Lewicki, R., Bunker B.B. (1996), Developing and Maintaining Trust in Work Relationships, w: Trust in Organisations: Frontiers of Theory and Researc, (eds.) Kramer R., Tyler T., Sage, Thousand Oaks

Loveless T. (1997), The structure of public confidence in education, "American Journal of Education" Vol. 105, No. 2

Luhmann N. (1979), Trust and Power, J. Wiley, New York

Luhmann N. (1998), Familiarity, Confidence, Trust: Problems and Alternatives, w: Trust: Making and Breaking Cooperative Relations, (ed.) Gambetta D., Basil Blackwell, Oxford

Mishler W., Rose R. (1997), Trust, distrust and skepticism: Popular evaluations of civil and political institutions in post-Communist societies, “Journal of Politics"Vol. 59

Mitchell T., Scott W. (1987), Leadership Failures, the Distrusting Public and Prospects of the Administrative State, "Public Administration Review" Vol. 47, No. 6

Newton K., Stolle D., Zmerli. S. (2018), Social and Political Trust, w: Oxford Handbook of Social and Political Trust, (ed.) Uslaner E., Oxford University Press, Oxford

Norris P. (2011), Democratic Deficit: Critical Citizens Revisited, Cambridge University Press, Cambridge

Norris P (1999), Introduction: the Growth of Critical Citizens, w: Critical Citizens: Global Support for Democratic Governanc, (ed. Norris P., Oxford University Press, Oxford

OECD (2013), Trust in government, policy effectiveness and the governance agenda, w: Government at a Glance 2013, OECD Publishing, Paris

Offe C. (1999), How Can We Trust Our Fellow Citizens?, w: Democracy and Trust, (ed.) Warren M., Cambridge University Press, Cambridge Offe C. (2006), Political Institutions and Social Power. Conceptual Explanations. w: Rethinking Political Institutions, (eds.) Shapiro I., Skowronek S., Galvin D., New York University Press, New York 
Osborne D., Gaebler T. (2005), Rządzić inaczej, Media Rodzina, Poznań

Pew Research Centre (2017), Public Trust in Government Remains Near Historic Lows as Partisan Attitudes Shift, http://www.peoplepress.org/2017/o5/o3/public-trust-in-government-remains-nearhistoric-lows-as-partisan-attitudes-shift/

Public Opinion In the European Union (2015), Special Eurobarometer 83, Spring, European Commission

Rosanvallon P. (2008a), Counter-Democracy. Politics In the Age of Distrust, Cambridge University Press, Cambridge

Rosanvallon P. (2008b), Nieufność i demokracja, „Dialogi polityczne” $\mathrm{nr} 10$

Sako M. (1992), Prices, Quality and Trust: Inter-Firm Relations in Britain \& Japan, Cambridge University Press, Cambridge

Stipak B. (1979), Citizen satisfaction with urban services: Potential misuse as a performance indicator, "Public Administration Review" Vol. 39

Szlaszyńska A., (2008), Społeczeństwo niepewności $w$ dobie kontr-demokracji. Wprowadzenie do myśli Pierre’a Rosanvallona, „Dialogi Polityczne" nr 10

Sztompka P. (1999), Trust: A Sociological Theory, Cambridge University Press, Cambridge

Sztompka P. (2007), Zaufanie. Fundament społeczeństwa, Wyd. Znak, Kraków

Tilly Ch., (2007), Democracy, Cambridge University Press, Cambridge Warren M.E., (2018), Trust and Democracy, w: Oxford Handbook of Social and Political Trust, (ed.) Uslaner E., Oxford University Press, Oxford

Williamson O. (1993), Calculativeness, Trust, and Economic Organization, "The Journal of Law \& Economics" Vol. 36, No. 1 